\title{
The role of perceived usefulness in the relationship between task - technology fit and individual job performance in ERP implementation - evidence from Vietnam's enterprises
}

\author{
Vo Van Nhi, Pham Tra Lam*
}

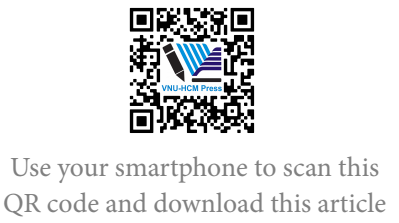

University of Economics, Ho Chi Minh

City

\section{Correspondence}

Pham Tra Lam, University of Economics, Ho Chi Minh City

Email: phamtralamais@ueh.edu.vn

\section{History}

- Received: 04/3/2019

- Accepted: 13/5/2019

- Published: 31/12/2019

DOI :10.32508/stdjelm.v3i4.587

\section{Check for updates}

\section{Copyright}

(c) VNU-HCM Press. This is an openaccess article distributed under the terms of the Creative Commons Attribution 4.0 International license.

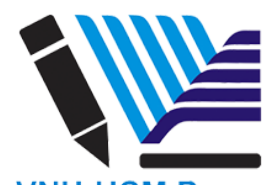

VNU-HCM Press

\begin{abstract}
In this context, the aim of the study was to examine the role of perceived usefulness in the relationship between individual job performance and task - technology fit in ERP environment. The study was done by 225 individuals. The results of the PLS_SEM analysis reveal ed that task — technology fit was significantly and positively related to perceived usefulness and individual job performance in ERP environment. Furthermore, perceived usefulness was significantly to individual job performance in ERP context. The results of this study added to the empirical evidence in the application of background theories including TTF, TAM and TTF models combined, DeLone and McLean IS Success Model, and ECM. Besides, they also added to the theoretical background of ERP's success. Furthermore, they support for companies who are planning to use ERP systems and the ERP vendors and implementers become more knowledgeable about ERP's success and forecast success when using ERP systems. Based on these results, the enterprise can plan the application to improve the efficiency of ERP systems. At the same time, the ERP vendors and developers can better advise and support their customers when delivering and deploying ERP systems.

Key words: Enterprise resource planning (ERP), job performance, perceived usefulness, task technology fit, Vietnam
\end{abstract}

\section{INTRODUCTION}

Companies all over the world have adopted enterprise resource planning (ERP) systems to integrate their business processes and stay competitive ${ }^{1}$. Because ERP is information system (IS), user perceptions about an ERP system play an important role in both usage and success of ERP ${ }^{2}$. Some organizations have applied the ERP system but users are nonadoption of the system ${ }^{3}$. In this case, job performance and job satisfaction are lower and turnover rates are higher ${ }^{4}$. In addition, if the job performance of individual is low, it will adversely affect the performance of organization ${ }^{5}$. As a critical indicator of ERP implementation success, it is important to examine possible factors that affect employee job performance ${ }^{4}$.

Bradford and Florin ${ }^{6}$ developed and tested a model of ERP implementation success which is measured by perceived organizational performance and user satisfaction. While the study of Bradford and Florin ${ }^{6}$ examined perceived organizational performance, the others explored the factors that can impact individual performance when using ERP systems such as Kositanurit et al. (2006), Park et al. (2007), Sykes et al. (2014), Sykes (2015) ${ }^{4,5,7,8}$. Kositanurit et al. provides evidence that system quality, utilization, and ease of use are the three important factors bearing on individual performance in ERP environment ${ }^{5}$. The study of Park et al. found that the users' ability to understand ERP knowledge influenced its performance and organizational support moderated the relationship between their absorptive capacity and performance ${ }^{7}$. Sykes et al. show workflow advice and software advice are associated with job performance ${ }^{4}$. Besides, that study found that the interactions of workflow and software get-advice, workflow and software giveadvice, and software get- and give-advice impacted job performance. Similarly, Sykes disclosures both traditional support structures and peer advice ties were found to influence the various outcomes including system satisfaction, job stress, job satisfaction and job performance ${ }^{8}$. On the individual level, the factors that are proven to have an impact on the job performance in ERP environment include system quality, utilization, ease of use, users' ability to understand ERP knowledge, workflow advice, software advice, traditional support structures and peer advice ties. Similar to the above studies, this work seeks to examine post - implementation employee job performance. However, we look for the impact of other factors including perceived usefulness and 
task - technology fit on job performance of users in ERP context. Based on Task- Technology Fit theory (TTF) ${ }^{9-11}$, TAM and TTF models combined ${ }^{12}$, DeLone and McLean IS Success Model ${ }^{2,13}$ and ECM (Expectation-Confirmation Model) ${ }^{14}$, this study examined the role of perceived usefulness in the relationship between individual job performance and task - technology fit in ERP environment.

This article is structured as follows. First, we describe the theoretical background on individual job performance, perceived usefulness and task - technology fit. Next, we present the research methodology used. Then, we present the findings. Finally, we present some conclusions and further work.

\section{LITERATURE REVIEW}

\section{Individual Job Performance}

According to TTF theory, performance benefits improve a range of performance outcomes ${ }^{15}$. The specific outcomes that have been examined in prior TTF research include system use/intention to use, job performance, satisfaction with technology, opinions regarding a technology, appropriation changes made, decision efficiency, decision quality, decision strategy employed, joint profit attained, number of ideas generated, quality of solution, task completion time, task accuracy, ability to perform tasks, perceived ease of use, perceived usefulness, perceived playfulness, perceived risk... ${ }^{15}$.

High performance implies that there is a mix between improved efficiency, improved effective and/ or improved quality ${ }^{10}$. It was often confused with productivity ${ }^{16}$. However, it is actually measured by more global variables such as the quality of outputs, job knowledge, leadership, or judgment ${ }^{16}$. In the traditional office, job performance is largely established by scanning for employees' presence and through direct and indirect observations ${ }^{16}$.

There exists a wide range of employee outcomes in ERP implementation, such as systems satisfaction, job stress, job satisfaction, and individual job performance $^{8}$. Job performance is a way to measure employee outcomes. Job performance is a good way of performing an employee's work ${ }^{8}$.

This study defined individual job performance in ERP environment was that the employee feels that with the help of ERP systems he/she can improve a range of performance outcomes.

\section{Task - Technology Fit}

Task - technology fit concept derives from the TaskTechnology Fit theory (TTF) ${ }^{9-11}$. According to TTF, the task - technology fit represents the degree of matching or alignment between the capabilities of an information system and the demands of the tasks that must be performed ${ }^{15}$. Base on TTF, this study defined $t$ ask - technology fit is the degree of relevance between the ability of ERP system and the tasks which an employee must perform.

Based on three theories including TTF, TAM and TTF models combined, and the DeLone and McLean IS Success Model (2013) ${ }^{13}$, this study develops the hypothesis H1. Firstly, according TTF, task - technology fit impact on performance benefit ${ }^{10}$ while individual job performance is used as an indicator of performance benefit ${ }^{15}$. Secondly, TAM and TTF models combined show that task - technology fit have significant effect on actual tool use ${ }^{12}$. At the same time, the user behavior has an impact on the job performance ${ }^{17}$. Finally, Peter et al. ${ }^{18}$ suggested that task compatibility impact on the IS success. Task compatibility is the fit or consistency between the task and the IS that supports that task ${ }^{13}$. In this study, task technology fit was defined similarly to task compatibility. Petter et al. ${ }^{18}$ measured the IS success based on the update DeLone and McLean ${ }^{2}$ IS success model, including information quality, system quality, service quality, intention to use/ use, user satisfaction, and net benefits. In this study, individual job performance was considered an indicator of net benefits. Based on the above arguments, this study developed hypothesis H1.

This hypothesis is also supported by several studies, such as Norzaidi et al. (2009), Bhattacherjee (2001), Teo and Bing (2008), Kositanurit et al. (2006), D'Ambra and Wilson (2004a), D'Ambra and Wilson (2004b), Wongpinunwatana et al. (2000), Goodhue et al. (1997), Goodhue and Thompson (1995), Goodhue (1995), Henseler (2015) 5,9,10,14,19-25. In particular, Staples and Seddon ${ }^{18}$ show that task - technology fit had an impact on individual job performance in both kinds of IT use, voluntary and mandatory. In this study, if an enterprise is using an ERP system, employees are required to use it. So Staples and Seddon ${ }^{18}$ strongly support the hypothesis $\mathrm{H} 1$.

H1: The task - technology $f$ it has a positive effect on the job performance of employee in ERP environment.

\section{Perceived Usefulness}

In TAM, perceived usefulness is "the degree to which a person believes that using particular system would enhance his or her job performance" ${ }^{26}$ (p.320). Perceived usefulness is a dimension of performance expectancy in $\mathrm{UTAUT}^{27}$. In this study, perceived usefulness of ERP systems was understood as the level at 
which the user believes ERP systems delivers good results for their work.

According TTF, task - technology fit impact on performance benefit ${ }^{10}$ and perceived usefulness can be used as an indicator of performance benefit ${ }^{15,28}$. Besides, Dishaw et al. ${ }^{12}$ suggested TAM and TTF models combined that demonstrated task - technology fit to have a significant impact on perceived usefulness. Based on TTF, TAM and TTF models combined and some studies such as Norzaidi et al. (2009), Tjahjono (2009), Chang (2008), Wu et al. (2007), Klopping and McKinney (2004), Dishaw and S trong (1999), Goodhue $(1995)^{9,10,19,29-33}$ hypothesis H2 is stated as follows:

H2: The task - technology fit has a positive effect o $n$ the perceived usefulness in ERP environment.

Based on three theories, namely TAM and TTF models combined, ECM (Expectation-Confirmation Model) ${ }^{14}$ and DeLone and McLean IS Success Model $(2013)^{2}$, this study developed the hypothesis H3. The first, according TAM and TTF models combined, perceived usefulness has effect on attitude toward use, then attitude toward use impact on intention to use, after that intention to use effect on actual tool use ${ }^{12}$. Next, ECM shows that perceived usefulness impact on IS continuance intention ${ }^{14}$. Last, user expectations was proven to have an impact on the IS success ${ }^{2}$. User expectations is the degree to which the user's perceptions about the IS are consistent with the actual IS 10 . In this study, perceived usefulness was close to the user expectations used in Petter et al. (2013) ${ }^{13}$. In general, TAM and TTF models combined, ECM and DeLone and McLean IS Success Model $(2013)^{2}$ have shown that the perceived usefulness of the information system had a positive impact on user behavior. At the same time, the user behavior had an impact on the job performance ${ }^{17}$.

Furthermore, some studies include Rajan and Baral (2015), Furneaux (2012), Sternad and Bobek (2013), Soto-Acosta et al. (2013), Elkhani et al. (2014), Zhang et al. (2013), Keong et al. (2012), Norzaidi et al. (2009), Youngberg et al. (2009), Calisir et al. (2009), Lee et al. (2010), Chang (2008), Wu et al. (2007), Ramayah and May- Chiun Lo (2007), Seymour et al. (2007) and Amoako- Gyampah and Salam (2004) have also shown that the perceived usefulness of IS/ ERP had a positive impact on user behavior $^{15,17,19,30,31,34-44}$. In addition, Goodhue demonstrated that the perceived usefulness of IS has a positive impact on the individual job performance in IT context $^{9}$. Based on the above arguments, this study hypothesized the following:
H3: The perceived usefulness of the ERP has a positive effect on the job performance of employee in ERP environment.

Figure 1 represents the proposed research model that was used for this research.

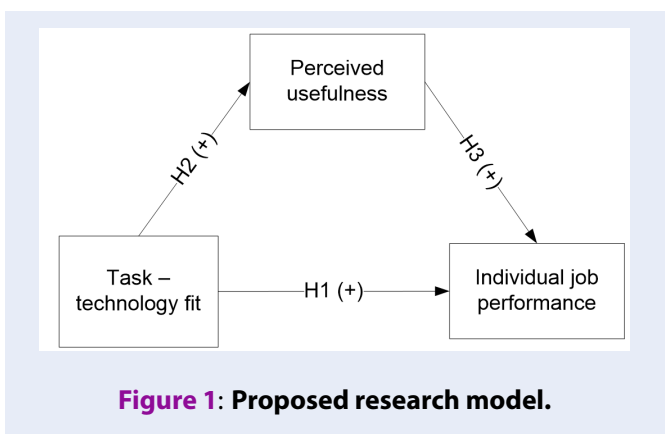

\section{METHODOLOGY}

\section{Measures}

All research constructs included in this study had multi-item scales derived from the relevant literature. Each item in the survey employed a 7-point Likert scale ( 1 = strongly disagree, $7=$ strongly agree $)$, and a not applicable (NA) option was available for the respondents to choose. We now elaborate our measures for the constructs. This study accepted scale of the individual job performance in ERP environment (PER) from Goodhue and Thompson ${ }^{10}$. PER is a first - order construct and reflective measures with 2 items. We measured task - technology fit (TTF) using a11-item scale adapted from Kositanurit et al. ${ }^{5}$ that captures the eight dimensions including currency (CURR), right data (RDAT), right level of detail (RDET), meaning (MEAN), ease of use (EOU), training (TRAI), authorization (AUT) and system reliability (REL). TTF is a high - order construct and reflective - reflective measures. The perceived usefulness (PU) was measured with 6 items adapted from Calisir and Calisir ${ }^{45}$ (from the TAM model). PU is a first - order construct and reflective measures.

\section{Data collection}

This study was conducted using quantitative means as it aimed to validate the proposed relationships between factors affecting individual job performance in ERP context. The research instrument was used a questionnaire distributed to the end-users (employees). The data were collected from June 2017 to August 2017. The questionnaires were sent by email or postal mail to an initial sample of 500 employees who 
are using ERP system. We collected 265 responses (response rate was $53 \%$ ). Baruch ${ }^{46}$ points out that for surveys addressed to individual, the average response rate is $52.7 \%$. Thus, the response rate of our study seems to be above average. Of the 265 employees, 225 employees from 49 companies gave usable responses at all points of measurement.

Table 1 presents the sample characteristics age, gender, education and average computer experience. The sample consisted of 161 (71.6\%) female and 64 (28.4 $\%)$ male. The Table 1 shows that $75.5 \%$ of the sampled individuals were fewer than 35 . In addition, $72 \%$ of the sampled individuals had bachelor degree. Average experience using an ERP system was 2.56 years.

\section{The Issue of Common Method Bias}

Because there was only one respondent for each individual, common method bias (CMB) was a potential problem. In this study, we took a number of steps suggested by Podsakoff et al. ${ }^{47}$ to reduce the possibility of common method bias. Firstly, we used multiple items for each construct and ensured the neutral wording of the items. Secondly, we assured respondents of the anonymity of their responses and emphasized that there were no right or wrong answers; each of these actions enabled them to answer questions as honestly as possible. Thirdly, we separated the measurement of predictors and criterion variables in the questionnaire to diminish the respondent's ability and motivation to use his/her prior responses to answer subsequent questions. Finally, we also used the Harman's single-factor test and the marker variable approach to control for common method variance (CMV). Results are discussed in data analysis and results section.

\section{DATA ANALYSIS AND RESULTS}

\section{Measurement model}

We estimated the internal consistency reliability, convergent validity, and discriminant validity of each measurement scale to assess the measurement model. We used two criterions for internal consistency were composite reliability (CR) and Cronbach's alpha. All the reflective constructs in our model show in Table 2 have a Cronbach's alpha over the cut off of 0.70 , as suggested by Hair et al. ${ }^{48}$. Similarly, a composite reliability (CR) of all the constructs is also higher than 0.7, as suggested by Fornell and Larcker ${ }^{49}$, implying high internal consistency.

Convergent validity is verified through the t-statistic for each factor loading. In PLS_SEM, we can use an indicator's outer loading. An outer loading should be above 0.7 and the $t$-statistic for each outer loading significant $^{48}$. Results of measurement models show that the items including AUT1, AUT2, REL1, REL2 and TRAI have outer loading was above 0.7 but the $t$ statistic for each outer loading was not significant. As such, the AUT1, AUT2, REL1, REL2 and TRAI were excluded from the TTF scales. Table 2 shows that results of final measurement models. A 11 factor loadings are greater than the typical cut off value of $0.7^{48}$ and significant at the $\mathrm{p}<0.001$ level. In this study, we also used the average variance extracted (AVE) to assess convergent validity. An AVE value of 0.50 or higher indicates that, on average, the construct explains more than half of the variance of its indicators. To establish discriminant validity, we used the HTMT criterion, Fornell - Larcker criterion and cross loadings. The results of discriminant validity are show in Table 3. Cross-factor loadings are reported in Appendix $A$.

The square root of the AVE of each construct should be higher than its highest correlation with any other construct $^{49}$. Table 3 shows that the square root of AVE exceeds the correlation between other constructs. In addition, all HTMT of constructs are significantly smaller than $1^{25}$. These results imply satisfactory discriminant validity.

\section{Structural model}

The structural model was examined to test the hypotheses. The $\mathrm{R}^{2}$, which is generated for each regression equation, indicates the explanatory power or variance explained of the latent endogenous variable. Figure 2 shows the structural model result.

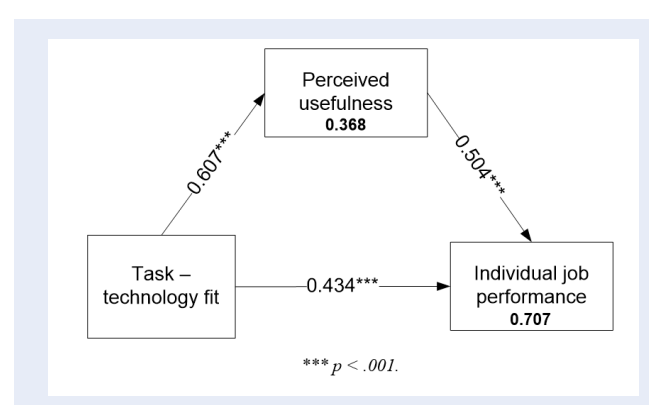

Figure 2: Result of proposed research model.

The PLS path analysis results show that task - technology fit was significantly related to individual job performance $(\beta=0.434, \mathrm{p}<0.001)$ and perceived usefulness $(\beta=0.607, \mathrm{p}<0.001)$ supporting hypotheses $\mathrm{H} 1$ and $\mathrm{H} 2$. Perceived usefulness was significantly related to individual job performance $(\beta=0.504, \mathrm{p}<0.001)$ supporting hypotheses $\mathrm{H} 3$. 


\begin{tabular}{|c|c|c|c|c|c|}
\hline Category & Frequency & Percentages (\%) & Category & Frequency & $\begin{array}{c}\text { Percentages } \\
\text { (\%) }\end{array}$ \\
\hline Age & & & Education & & \\
\hline$<35$ & 170 & 75.5 & Master & 7 & 3.1 \\
\hline $35-45$ & 47 & 20.9 & Bachelor & 162 & 72 \\
\hline$>45$ & 8 & 3.6 & Colleges & 43 & 19.1 \\
\hline Gender & & & Others & 13 & 5.8 \\
\hline Male & 64 & 28.4 & Average computer & 2.56 & \\
\hline 56 Female & 161 & 71.6 & & & \\
\hline
\end{tabular}

The external variables including task - technology fit and perceived usefulness could explain 70.7 percent variance in individual job performance $\left(\mathrm{R}^{2}=0.707\right)$. Task - technology fit explained 36.8 percent of variance of perceived usefulness $\left(\mathrm{R}^{2}=0.368\right)$.

Next, we assessed the predictive relevance of the path model by $\mathrm{Q}^{2}$ values. All $\mathrm{Q}^{2}$ values are considerably above zero $\left(\mathrm{Q}^{2}\right.$ of individual job performance is 0.631 and $\mathrm{Q}^{2}$ of perceived usefulness is 0.261 ), thus providing support for the model's predictive relevance regarding the endogenous latent variables.

The final assessments address the $\mathrm{f}^{2}$ and $\mathrm{q}^{2}$ effect sizes. Table 4 summarizes the results of the $\mathrm{f}^{2}$ and $\mathrm{q}^{2}$ effect sizes with respect to all the relationships in the model. Target constructs appear in the first row, whereas the predecessor constructs are in the first column. Table 4 shows TTF has a large effect size of $0.405(0.290)$ on PER and of 0.583 (0.404) on PU. Similarly, PU has a large effect size of $0.546(0.345)$ on PER.

Additionally, the variance inflation factor (VIF) was assessed to check multicollinearity. The collinearity diagnostics given inTable 5 shows that VIF for the independent variables higher than 0.20 (lower than 5) which further suggests that multicollinearity does not exist among the independent variables.

\section{MEDIATION ANALYSIS}

In this study, we examined a mediator variable, intervenes between two other related constructs. Specifically, we examined the role of perceived usefulness in the relationship from task - technology fit to individual job performance in ERP context. Table 6 shows result of mediator variable. We find that both direct effect and indirect effect are significant. Our finding provided empirical support for the mediating role of perceived usefulness in the relationship from task technology fit to individual job performance in ERP context.
Because path coefficient of the relationship from task - technology fit to individual job performance was 0.434 and significant, path coefficient of the relationship from task - technology fit to perceived usefulness was 0.607 and significant, and path coefficient of the relationship from perceived usefulness to individual job performance was 0.504 and significant, perceived usefulness represents complementary mediation of the relationship from task - technology fit to individual job performance in ERP context.

\section{The Issue of Common Method Bias}

We used the Harman's single-factor test and the marker variable approach to control for CMV in PLS analysis. Result of Harman's single-factor test by EFA shows that one factor only account for $40.537 \%$ of the total variance. In this case, $\mathrm{CMV}$ is not a serious prob$\operatorname{lem}^{50}$.

The marker variable approach was conducted by using marker variable. The first stage, we involved survey questionnaire that had a question was "Do you really like black coffee?" - this question was a marker variable $^{24}$. The next stage, we used PLS to test path coefficient of the relationship from marker variable to other variable in proposal model including perceived usefulness, task - technology fit and individual job performance. Analysis results showed that all path coefficients of the relationships from marker variable to perceived usefulness, task - technology fit and individual job performance were less than $0.3(-0.102$, 0.094 and -0.060 ). This finding suggests that CMV was not a serious problem in this study.

Besides, we also based on VIF to test CMB. Table 5 show that all VIFs resulting from a full collinearity test were lower than 3.3, the model can be considered free of CMB. 
Table 2: Results summary of measurement models

\begin{tabular}{|c|c|c|c|c|c|c|c|}
\hline \multirow{3}{*}{$\begin{array}{c}\text { Latent } \\
\text { variable }\end{array}$} & \multirow{3}{*}{ Indicators } & \multicolumn{3}{|c|}{ Convergent validity } & \multicolumn{2}{|c|}{$\begin{array}{l}\text { Internal consistency } \\
\text { reliability }\end{array}$} & \multirow{3}{*}{$\begin{array}{l}\text { Discriminant } \\
\text { validity }\end{array}$} \\
\hline & & Loadings & $\begin{array}{l}\text { Indicator } \\
\text { reliability }\end{array}$ & AVE & $\begin{array}{l}\text { Composite } \\
\text { reliability }\end{array}$ & $\begin{array}{l}\text { Cronbach's } \\
\text { Alpha }\end{array}$ & \\
\hline & & $>0.7$ & $>0.5$ & $>0.5$ & $0.6-0.95$ & $0.6-0.95$ & \\
\hline \multirow[t]{2}{*}{ PER } & $\begin{array}{l}\text { PER1: ERP systems system has a } \\
\text { positive impact on my productivity } \\
\text { in my job }\end{array}$ & $0.966^{\star * *}$ & 0.933 & 0.937 & 0.932 & 0.967 & Yes \\
\hline & $\begin{array}{l}\text { PER2 : ERP systems is an important } \\
\text { aid to me in the performance of my } \\
\text { job }\end{array}$ & $0.970^{* * *}$ & 0.941 & & & & \\
\hline \multirow[t]{6}{*}{$\mathrm{PU}$} & $\begin{array}{l}\text { PU1 : Using ERP systems in my job } \\
\text { increased my productivity }\end{array}$ & $0.884^{\star * *}$ & 0.781 & 0.768 & 0.939 & 0.952 & Yes \\
\hline & $\begin{array}{l}\text { PU2: I found ERP systems useful in } \\
\text { my job }\end{array}$ & $0.855^{* * *}$ & 0.731 & & & & \\
\hline & $\begin{array}{l}\text { PU3: Using ERP systems improved } \\
\text { my job performance }\end{array}$ & $0.854^{* * *}$ & 0.729 & & & & \\
\hline & $\begin{array}{l}\text { PU4: Using ERP systems enhanced } \\
\text { my effectiveness on the job }\end{array}$ & $0.913^{* * *}$ & 0.834 & & & & \\
\hline & $\begin{array}{l}\text { PU5: Using ERP systems in my job } \\
\text { enabled to accomplish tasks more } \\
\text { quickly }\end{array}$ & $0.900^{* * *}$ & 0.810 & & & & \\
\hline & $\begin{array}{l}\text { PU6: Using ERP systems made it } \\
\text { easier to do my job }\end{array}$ & $0.849^{* * *}$ & 0.721 & & & & \\
\hline CURR & $\begin{array}{l}\text { CURR: The data provide by ERP } \\
\text { systems is up-to-date enough for my } \\
\text { purposes }\end{array}$ & 1.000 & 1.000 & 1.000 & 1.000 & 1.000 & Yes \\
\hline RDAT & $\begin{array}{l}\text { RDAT: ERP systems available to me } \\
\text { is missing critical data that are very } \\
\text { useful to me in my job }\end{array}$ & 1.000 & 1.000 & 1.000 & 1.000 & 1.000 & Yes \\
\hline RDET & $\begin{array}{l}\text { RDET : ERP systems maintains data } \\
\text { at an appropriate level of detail for } \\
\text { my group's tasks }\end{array}$ & 1.000 & 1.000 & 1.000 & 1.000 & 1.000 & Yes \\
\hline MEAN & $\begin{array}{l}\text { MEAN: The exact definition of data } \\
\text { fields relating to my tasks is easy to } \\
\text { find out }\end{array}$ & 1.000 & 1.000 & 1.000 & 1.000 & 1.000 & Yes \\
\hline \multirow[t]{2}{*}{ EOU } & $\begin{array}{l}\text { EOU1: It is easy to learn how to use } \\
\text { ERP systems }\end{array}$ & $0.953^{* * *}$ & 0.908 & 0.912 & 0.904 & 0.954 & Yes \\
\hline & $\begin{array}{l}\text { EOU2: ERP systems I use is conve- } \\
\text { nient and easy to use }\end{array}$ & $0.957^{* * *}$ & 0.916 & & & & \\
\hline
\end{tabular}

${ }^{* * *} \mathrm{p}<0.001$. 
Table 3: Results of discriminant validity

\begin{tabular}{|c|c|c|c|c|c|c|c|c|c|}
\hline & Mean & SD & CURR & EOU & MEAN & PER & PU & RDAT & RDET \\
\hline CURR & 4.50 & 1.530 & 1.000 & & & & & & \\
\hline \multirow[t]{2}{*}{ EOU } & 4.428 & 1.383 & 0.390 & 0.955 & & & & & \\
\hline & & & 0.410 & & & & & & \\
\hline \multirow[t]{2}{*}{ MEAN } & 4.62 & 1.346 & 0.387 & 0.535 & 1.000 & & & & \\
\hline & & & 0.387 & 0.562 & & & & & \\
\hline \multirow[t]{2}{*}{ PER } & 5.029 & 1.327 & 0.351 & 0.716 & 0.634 & 0.968 & & & \\
\hline & & & 0.362 & 0.779 & 0.657 & & & & \\
\hline \multirow[t]{2}{*}{ PU } & 5.231 & 1.157 & 0.314 & 0.576 & 0.532 & 0.767 & 0.876 & & \\
\hline & & & 0.324 & 0.621 & 0.547 & 0.817 & & & \\
\hline \multirow[t]{2}{*}{ RDAT } & 3.96 & 1.565 & 0.143 & 0.301 & 0.147 & 0.110 & 0.026 & 1.000 & \\
\hline & & & 0.143 & 0.317 & 0.147 & 0.114 & 0.049 & & \\
\hline \multirow[t]{2}{*}{ RDET } & 4.69 & 1.338 & 0.618 & 0.375 & 0.519 & 0.492 & 0.418 & 0.125 & 1.000 \\
\hline & & & 0.618 & 0.394 & 0.519 & 0.508 & 0.433 & 0.125 & \\
\hline
\end{tabular}

Number of the top rows: Fornell - Larcker criterion

Number of the below rows: HTMT criterion

Table 4: $\mathbf{f}^{2}$ and $\mathbf{q}^{2}$ effect sizes

\begin{tabular}{ccccc}
\hline & \multicolumn{2}{c}{$\mathrm{f}^{2}$ effect sizes } & \multicolumn{2}{c}{$\mathrm{q}^{2}$ effect sizes } \\
& PER & PU & PER & PU \\
TTF & 0.405 & 0.583 & 0.290 & 0.345 \\
PU & 0.546 & & 0.404 & \\
\hline
\end{tabular}

Table 5: Collinearity statistic

\begin{tabular}{cc}
\hline Construct & VIF \\
Task - technology fit (TTF) & 1.583 \\
Perceived usefulness (PU) & 1.583 \\
\hline
\end{tabular}

Table 6: Significance analysis of the direct and indirect effects

\begin{tabular}{|c|c|c|c|c|c|c|c|c|}
\hline & $\begin{array}{l}\text { Direct } \\
\text { effect }\end{array}$ & $\begin{array}{l}95 \% \text { confidence } \\
\text { interval of the } \\
\text { direct effect }\end{array}$ & $\begin{array}{c}t \\
\text { value }\end{array}$ & $\begin{array}{l}\text { Signifi- } \\
\text { cance } \\
(\mathrm{p}<0.05) ?\end{array}$ & $\begin{array}{l}\text { Indirect } \\
\text { effect }\end{array}$ & $\begin{array}{l}95 \% \text { confidence } \\
\text { interval of the } \\
\text { indirect effect }\end{array}$ & $\begin{array}{c}t \\
\text { value }\end{array}$ & $\begin{array}{c}\text { Significance } \\
(\mathrm{p}<0.05) ?\end{array}$ \\
\hline TTF $->$ PER & 0.434 & {$[0.314 ; 0.541]$} & $7.32 \epsilon$ & Yes & 0.306 & {$[0.230 ; 0.394]$} & 7.14 & Yes \\
\hline
\end{tabular}




\section{DISCUSSION}

The results of this research supported most of the proposed relationships in the structural model. Most were consistent with the previous study results. Task - technology fit was significantly and positively related to perceived usefulness and individual job performance in ERP environment ( $\mathrm{H} 1$ and $\mathrm{H} 2$ are supported). Perceived usefulness was significantly and positively related to individual job performance in ERP context (H3 is supported).

In ERP context, Kositanurit et al. ${ }^{5}$ found that task technology fit was the important factor bearing on individual performance. The result of this study is similar to the result of Kositanurit et al. ${ }^{5}$. The new findings of this study are that we provided empirical evidence on the impact of task - technology fit to perceived usefulness and of perceived usefulness to individual job performance in ERP environment.

\section{CONCLUSIONS}

This study added to the empirical evidence in the application of background theories including TTF, TAM and TTF models combined, DeLone and McLean IS Success Model, and ECM. Besides, the results of this study also added to the theoretical background of ERP's success, namely, the individual job performance of employee in ERP context. Specifically, factors including perceived usefulness and tasks and technology fit have a significant impact on the individual job performance employee in ERP context. Furthermore, the results of this study help companies who are planning to use ERP systems and the ERP vendors and implementers become more knowledgeable about ERP's success and forecast success when using ERP systems. In this study, the ERP success was measured by job performance of employee. The factors that have been tested are the impact on the individual job performance of employee in ERP context including perceived usefulness and tasks and technology fit. Based on these results, the enterprise can plan the application to improve the efficiency of ERP systems. At the same time, the ERP vendors and developers can better advise and support their customers when delivering and deploying ERP systems.

This study has a few limitations. ERP implementations are complex and take time to complete ${ }^{51,52}$. However, this study was restricted to the shakedown phase of the implementation, which is widely acknowledged to be the most critical in terms of continuation or abandonment of $\mathrm{ERP}^{53}$. It could be that these findings might change over time, with some support structures gaining or losing influence on the outcomes of interest. Work that gives greater consideration to time would enrich our understanding of this phenomenon. Thus, an area for possible future work would be to examine ERP implementations and support structures over a significantly longer period of time-that is, across all phases of an implementation. Besides, this study collected data from ERP user in many kinds of enterprises; therefore, there is a restriction related to applicability of this study for each specific enterprise group.

This study chose an approach for the employee to assess his or her job performance in ERP context that is not evaluated by the supervisor of the employee. Future research should collect data through supervisors to measure the job performance of the employee in ERP context.

\section{ABBREVIATIONS}

AVE: Average variance extracted

CMB: Common method bias

CMV: Common method variance

CR: Composite reliability

ECM: Expectation-Confirmation Model

EFA: Exploratory factor analysis

ERP: Enterprise Resource Planning

IS: Information system

HTMT: Heterotrait-monotrait ratio of correlations

PLS_SEM: Partial Least Squares Based Structural Equation Modeling

TAM: Technology Acceptance model

TTF: Task-Technology Fit theory

UTAUT: Unified theory of acceptance and use of technology

VIF: Variance inflation factor

\section{COMPETING INTERESTS}

The authors declare that they have no conflicts of interest.

\section{AUTHORS' CONTRIBUTIONS}

Vo Van Nhi and Pham Tra Lam have contributed in conducting experiments, getting hold of data and writing the manuscript. Pham Tra Lam has contributed explanation of data and revising the manuscript.

\section{A. APPENDIX}

Cross loading 


\begin{tabular}{cccccccc}
\hline & & & & & \\
& CURR & EOU & MEAN & PER & PU & RDAT & RDET \\
CURR & $\mathbf{1 . 0 0 0}$ & 0.390 & 0.387 & 0.351 & 0.314 & 0.143 & 0.618 \\
EOU1 & 0.358 & $\mathbf{0 . 9 5 3}$ & 0.480 & 0.633 & 0.503 & 0.311 & 0.328 \\
EOU2 & 0.386 & $\mathbf{0 . 9 5 7}$ & 0.542 & 0.732 & 0.595 & 0.264 & 0.387 \\
MEAN & 0.387 & 0.535 & $\mathbf{1 . 0 0 0}$ & 0.634 & 0.532 & 0.147 & 0.519 \\
PER1 & 0.290 & 0.694 & 0.626 & $\mathbf{0 . 9 6 6}$ & 0.721 & 0.110 & 0.418 \\
PER2 & 0.386 & 0.692 & 0.601 & $\mathbf{0 . 9 7 0}$ & 0.762 & 0.103 & 0.531 \\
PU1 & 0.251 & 0.513 & 0.467 & 0.723 & $\mathbf{0 . 8 8 4}$ & 0.044 & 0.379 \\
PU2 & 0.239 & 0.420 & 0.442 & 0.633 & $\mathbf{0 . 8 5 5}$ & -0.060 & 0.422 \\
PU3 & 0.318 & 0.469 & 0.358 & 0.633 & $\mathbf{0 . 8 5 4}$ & 0.039 & 0.356 \\
PU4 & 0.292 & 0.485 & 0.469 & 0.679 & $\mathbf{0 . 9 1 3}$ & 0.013 & 0.382 \\
PU5 & 0.250 & 0.535 & 0.543 & 0.687 & $\mathbf{0 . 9 0 0}$ & 0.030 & 0.342 \\
PU6 & 0.302 & 0.593 & 0.506 & 0.669 & $\mathbf{0 . 8 4 9}$ & 0.064 & 0.323 \\
RDAT & 0.143 & 0.301 & 0.147 & 0.110 & 0.026 & $\mathbf{1 . 0 0 0}$ & 0.125 \\
RDET & 0.618 & 0.375 & 0.519 & 0.492 & 0.418 & 0.125 & $\mathbf{1 . 0 0 0}$ \\
\hline
\end{tabular}

\section{REFERENCES}

1. Wei CC, Wang MJJ. A comprehensive framework for selecting an ERP system. International journal of project management. 2004;22(2):161-169.

2. Delone WH, Mclean ER. The DeLone and McLean model of information system success, a ten-year update. Journal of Managment Information Systems. 2003;19(4):9-30.

3. Plaza M, Rohlf K. Learning and performance in ERP implementation projects: A learning-curve model for analyzing and managing consulting costs. International Journal of Production Economics. 2008;115(1):72-85.

4. Sykes TA, Venkatesh V, Johnson JL. Enterprise system implementation and employee job performance, Understanding the role of advice networks. MIS Quarterly. 2014;30(1):5172 .

5. Kositanurit B, Ngwenyama O, Osei-Bryson KM. An exploration of factors that impact individual performance in an ERP environment: an analysis using multiple analytical techniques. European Journal of Information Systems. 2006;15(6):556-568.

6. Bradford M, Florin J. Examining the role of innovation diffusion factors on the implementation success of enterprise resource planning systems. International Journal of Accounting Information Systems. 2003:4:205-225.

7. Park JH, Suh HJ, Yang HD. Perceived absorptive capacity of individual users in performance of Enterprise Resource Planning (ERP) usage: The case for Korean firms. Information \& Management. 2007;44(3):300-312.

8. Sykes TA. Support Structures and Their Impacts on Employee Outcomes, A Longitudinal Field Study of an Enterprise System Implementation. MIS Quarterly;2015(2):473-495.

9. Goodhue DL. Understanding user evaluations of information systems. Management Science. 1995;41(12):1827-1844.

10. Goodhue DL, Thompson RL. Task-technology fit and individual performance. Management Information Systems Quarterly. 1995;19(2):213-236.

11. Zigurs I, Buckland BK. A theory of task/technology fit and group support systems effectiveness. Management Information Systems Quarterly. 1998;22(3):313-334.

12. Dishaw M, Strong D, Bandy DB. Extending the tasktechnology fit model with self-efficacy constructs. AMCIS 2002 Proceedings. 2002;p. 143.

13. Petter S, Delone W, Mclean ER. Information systems success, The quest for the independent variables. Journal of Management Information Systems. 2013;29(4):7-62.

14. Bhattacherjee A. Understanding information systems continuance, an expectation-confirmation model. MIS quarterly. 2001;p. 351-370.

15. Furneaux B. Chapter 5, Task - Technology Fit Theory, A Survey and Synopsis of the Literature. In: Dwivedi YK, Wade MR, Schneberger SL, editors. Trong Information Systems Theory, Explaining and Predicting Our Digital Society. vol. 1. USA: Springer; 2012. p. 87-106.

16. Ruppel $\mathrm{CP}$, Harrington SJ. Telework: An innovation where nobody is getting on the bandwagon. ACM SIGMIS Database: the DATABASE for Advances in Information Systems. 1995;26(2-3):87-104.

17. Rajan CA, Baral R. Adoption of ERP system: An empirical study of factors influencing the usage of ERP and its impact on end user. IIMB Management Review. 2015;27(2):105-117.

18. Staples DS, Seddon P. Testing the technology-to-performance chain model. Journal of Organizational and End User Computing (JOEUC). 2004;16(4):17-36.

19. Norzaidi MD, et al. Towards a holistic model in investigating the effects of intranet usage on managerial performance: a study on Malaysian port industry. Maritime Policy \& Management. 2009;36(3):269-289.

20. Teo TS, Men B. Knowledge portals in Chinese consulting firms: a task-technology fit perspective. European Journal of Information Systems. 2008;17(6):557-574.

21. D'Ambra J, Wilson CS. Use of the World Wide Web for international travel, Integrating the construct of uncertainty in information seeking and the task-technology fit (TTF) model. Journal of the American Society for Information Science and Technology. 2004;55(8):731-742.

22. D'Ambra J, Wilson CS. Explaining perceived performance of the World Wide Web, uncertainty and the task-technology fit model. Internet Research. 2004;14(4):294-310. 
23. Wongpinunwatana N, Ferguson C, Bowen P. An experimental investigation of the effects of artificial intelligence systems on the training of novice auditors. Managerial Auditing Journal. 2000;15(6):306-318.

24. Goodhue D, Littlefield R, Straub DW. The measurement of the impacts of the IIC on the end-users: The survey. Journal of the American Society for Information Science. 1997;48(5):454465.

25. Henseler J, Ringle CM, Sarstedt M. A new criterion for assessing discriminant validity in variance-based structural equation modeling. Journal of the academy of marketing science. 2015;43(1):115-135.

26. Davis FD, Bagozzi RP, Warshaw PR. User acceptance of computer technology, A comparison of two theoretical models. Management Science. 1989;35(8):982-1003.

27. Venkatesh V, Morris MG, Davis GB, Davis FD. User acceptance of information technology, Toward a unified view. Management Information Systems Quarterly. 2003;27(3):425-479.

28. Lindell MK, Whitney DJ. Accounting for common method variance in cross-sectional research designs. Journal of Applied Psychology. 2001;86(1):114-121.

29. Tjahjono B. Supporting shop floor workers with a multimedia task-oriented information system. Computers in Industry. 2009;60(4):257-265.

30. Chang HH. Intelligent agent's technology characteristics applied to online auctions' task, A combined model of TTF and TAM. Technovation. 2008;28(9):564-577.

31. Wu JH, Chen YC, Lin LM. Empirical evaluation of the revised end user computing acceptance model. Computers in Human Behavior. 2007;23(1):162-174.

32. Klopping IM, McKinney E. Extending the technology acceptance model and the task-technology fit model to consumer e-commerce. Information Technology, Learning \& Performance Journal. 2004;22(1).

33. Dishaw M, Strong DM, Bandy DB. Extending the technology acceptance model with task-technology fit constructs. Information \& management. 1999;36(1):9-21.

34. Sternad S, Bobek S. Impacts of TAM-based external factors on ERP acceptance. Procedia Technology. 2013;9:33-42.

35. Soto-Acosta P, Ramayah T, Popa S. Explaining intention to use an enterprise resource planning system: a replication and extension. Tehniki vjesnik. 2013;20(3):397-405.

36. Elkhani N, Soltani S, Ahmad MN. The effects of transformational leadership and ERP system self-efficacy on ERP system usage. Journal of Enterprise Information Management. 2014;27(6):759-785

37. Zhang $S, G a o P, G e$ Z. Factors impacting end-users' usage of ERP in China. Kybernetes. 2013;42(7):1029-1043.

38. Ling Keong $M$, et al. Explaining intention to use an enterprise resource planning (ERP) system: an extension of the UTAUT model. Business Strategy Series. 2012;13(4):173-180.

39. Youngberg $E$, Olsen D, Hauser K. Determinants of professionally autonomous end user acceptance in an enterprise re- source planning system environment. International journal of information management. 2009;29(2):138-144.

40. Calisir F, Gumussoy CA, Bayram A. Predicting the behaviora intention to use enterprise resource planning systems, An exploratory extension of the technology acceptance model. Management research news. 2009;32(7):597-613.

41. Lee $D$, et al. The effect of organizational support on ERP implementation. Industrial management \& data systems. 2010;110(2):269-283.

42. Ramayah T, May-Chiun L. Impact of shared beliefs on perceived usefulness and ease of use in the implementation of an enterprise resource planning system. Management Research News. 2007;30(6):420-431.

43. Seymour L, Makanya W, Berrangé S. End-users' acceptance of enterprise resource planning systems: An investigation of antecedents. Proceedings of the 6th annual ISOnEworld conference. 2007;p. 1-22.

44. Amoako-gyampah K, SALAM AF. An extension of the technology acceptance model in an ERP implementation environment. Information \& management. 2004;41(6):731-745.

45. Calisir F, Calisir F. The relation of interface usability characteristics, perceived usefulness, and perceived ease of use to end-user satisfaction with enterprise resource planning (ERP) systems. Computers in human behavior. 2004;20(4):505-515.

46. Baruch Y. Survey response rate levels and trends in organizational research. Sage Journal. 2008;61(8):1139-1160.

47. Podsakoff PM, Mackenzie SB, Lee JY, Podsakoff NP. Common method biases in behavioral research, a critical review of the literature and recommended remedies. J Appl Psychol. 2003;88(5):879-903.

48. Hair JF, Hult GTM, Ringle CM, Sarstedt M. A PRIMER ON PARTIAL LEAST SQUARES STRUCTURAL EQUATION MODELING (PLS-SEM);. H. D. Tanyani and S. Gilaniani (2015). Enterprise Resource Planning Readiness Assessment. Arabian Journal of Business and Management Review; 2016, 5(2), 8 -13.

49. Fornell C, Larcker DF. Structural equation models with unobservable variables and measurement error, Algebra and statistics. 1981; p. 382-388.

50. Podsakoff PM, Organ DW. Self-Reports in Organizational Research, Problems and Prospects. Journal of Management 1986;12(4):531-544.

51. Markus ML, Tanis C. "The Enterprise System ExperienceFrom Adoption to Success" in framing the domains of it management, Projecting the Future Through the Past. Pinnaflex Educational Resources, Inc; 2000.

52. Volkoff O, Strong DM, Elmes MB. Technological embeddedness and organizational change. Organization Science. 2007;18(5):832-848.

53. Morris MG, Venkatesh V. Job characteristics and job satisfaction: understanding the role of enterprise resource planning system implementation. Mis Quarterly. 2010;34(1):134-161. 


\title{
Vai trò của cảm nhận tính hữu dụng trong mối quan hệ giữa sự phù hợp giữa nhiệm vụ và công nghệ với kết quả công việc cá nhân trong môi trường ứng dụng erp - bằng chứng từ các doanh nghiệp Việt Nam
}

\author{
Võ Văn Nhị, Phạm Trà Lam*
}

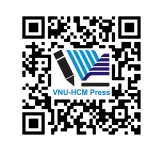

Use your smartphone to scan this QR code and download this article

\section{TÓM TẮT}

Mục tiêu của nghiên cứu này là xem xét vai trò của sự hữu ích trong mối quan hê giữa kết quả công việc cá nhân và sự phù hợp giữa nhiệm vụ và công nghệ trong môi trường ứng dụng ERP. Nghiên cứu được thực hiện bằng các bảng khảo sát được trả lời bởi 225 cá nhân. Kết quả phân tích PLS_SEM cho thấy sự phù hợp giữa nhiệm vụ và công nghệ có tác động tích cực đáng kể đến cảm nhận tính hữu dụng và kết quả công việc cá nhân trong môi trường ERP. Ngoài ra, cảm nhận tính hữu dung cũng có tác đông đáng kể đến kết quả công viêcc cá nhân trong môi trường ERP. Kết quả của nghiên cứu này đã bổ sung bằng chứng thực nghiệm trong việc áp dụng các lý thuyết nền tảng bao gồm các mô hình TTF, TAM và TTF kết hợp, mô hình thành công của hệ thống thông tin của DeLone và McLean và mô hình ECM. Bên canh đó, các kết quả này cũng bổ sung vào nền tảng lý thuyết về sự thành công trong ứng dụng ERP. Từ các kết quả nghiên cứu này, các công ty đang có kế hoạch sử dụng hệ thống ERP và các nhà cung cấp và triển khai ERP có các cơ sở lý thuyết vững chắc về sự thành công của ERP và dự báo sự thành công khi quyết địinh ứng dụng hệ thống ERP. Dựa trên những kết quả này, doanh nghiệp có thể lập kế hoạch ứng dụng để cải thiện hiệu quả của hệ thống ERP. Đồng thời, các nhà cung cấp và triển khai ERP có thể tư vấn và hỗ trợ khách hàng tốt hơn khi cung cấp và triển khai hệ thống.

Từ khoá: Hoạch định nguồn lực doanh nghiệp (ERP), kết quả công việc, nhận thức tính hữu dụng, sự phù hợp giữa nhiệm vụ và công nghệ, Việt Nam
Trương Đại học Kinh tế TP.HCM

Liên hệ

Phạm Trà Lam, Trường Đại học Kinh tế TP.HCM

Email: phamtralamais@ueh.edu.vn

Lịch sử

- Ngày nhận: 04/3/2019

- Ngày chấp nhận: 13/5/2019

- Ngày đăng: 31/12/2019

DOI : 10.32508/stdjelm.v3i4.587

\section{Check for updates}

\section{Bản quyền}

๑ Đ ĐHQG Tp.HCM. Đây là bài báo công bố mở được phát hành theo các điều khoản của the Creative Commons Attribution 4.0 International license.

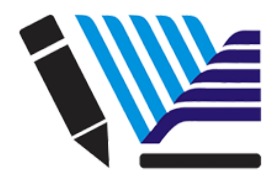

VNU-HCM Press
Trích dẫn bài báo này: Nhị V V, Lam $\mathrm{P} T$. Vai trò của cảm nhận tính hữu dụng trong mối quan hệ giữa sự phù hợp giữa nhiệm vụ và công nghệ với kết quả công việc cá nhân trong môi trường ứng dụng erp - bằng chứng từ các doanh nghiệp Việt Nam. Sci. Tech. Dev. J. - Eco. Law Manag.; 3(4):451-461. 